\title{
HOUSING SUSTAINABILITY IN HONG KONG: A MARKET-BASED PERSPECTIVE
}

\author{
EDDIE HUI, K.H. YU and VIVIAN HO \\ Hong Kong Polytechnic University
}

\begin{abstract}
While sustainability has been under heated debate in the past 20 years, practical issues such as housing sustainability have been overlooked. This research introduces a two-tier analytical framework based on the environmental, economic and social dimensions of housing sustainability. This provides a market-oriented understanding on the issue of housing sustainability. The findings suggest that a balanced, yet flexible, housing policy which emphasizes the coordinated functioning of both the public and the private sectors in the housing market. This calls for more attention from the government to older, lowerincome districts and the needs of present generations.
\end{abstract}

Keywords: Cluster analysis, linear regression, planning policy, housing sustainability.

\section{INTRODUCTION}

Hong Kong is one of the most densely populated areas in the world. In the last seven years, the total population has increased by $16 \%$, to 7 million. However, Hong Kong only has a total land area of a little more than 1,000 square kilometres with only $21 \%$ of such being developed. The undeveloped parts of Hong Kong are mostly undevelopable, either due to difficult terrain or the need to preserve the natural environment. Around $38 \%$ of the total land area of Hong Kong is designated as country parks (Leung, 2000). The pressure on land for development is tremendous, due to increasing population and economic development. There is a paramount need to ensure Hong Kong's long-term sustainability.

The Hong Kong SAR Government (2000), in its most recent white paper, emphasizes that sustainable development is a pressing issue that has to be tackled. The territory is facing tremendous problems, not only from potential increases in population, but also the corresponding need for additional housing and other related facilities. The Hong Kong Housing Bureau (1998) also sees the need to increase housing supply by modifying development densities to meet the goal of "providing adequate/affordable housing for households". However, such only applies to the lower-income households in Hong Kong, 
as they are the ones who rely on government assistance for their housing needs. As far as the higher income households are concerned, their choices of housing may be conflicting with the government's ideas of sustainable development.

In view of the possible influence of housing to the overall sustainability of Hong Kong, this research aims to explore the issue of housing sustainability, with a market-oriented twist. Preferences of individuals regarding housing are needed to be known before any planning policies can be made. Therefore, before discussing the government's policies on sustainability, we need a basic understanding of what people want the most. Selected districts in Hong Kong will be scrutinized, in terms of the housing demand/supply situations. These districts will then be divided into different clusters and different settings/combinations of land use can be identified. From that, a favourable land use pattern can be found and the characteristics of this cluster of districts will provide a starting point for the discussion of a sustainable housing policy.

This paper will be divided into five sections. The first section is an introduction which provides the rationale of studying the topic of housing sustainability in Hong Kong. The second section provides a literature review in which the definition of "sustainability" will be explored and previous researches on sustainability of housing will be reviewed. The third section is the framework and methodology section. The assumptions and structure of the two-tier analytical framework of this paper will be delineated. This will be followed by a discussion on the findings and implications on housing policy. The last part of the paper will conclude the study.

\section{LITERATURE REVIEW}

In discussions regarding housing sustainability, with the exception of environmental conservation, numerous aspects of individual needs also have to be considered as well. According to Chiu (2000), "a policy on sustainable housing development should cater for the housing needs of not only this generation but also of those to come. In addition to the inter-generation housing equity, the housing inequality of this generation should also be addressed". This poises a dilemma between resource conservation for the benefit of future generations and the improvement on livability for the present generation. A definition of basic living standards may be involved for this and future generations, given the known sustainability of the existing housing system (Chiu, 2000). Dissensions between generational resource usage aside, sustainable housing should not be just about meeting the basic needs, but also improving the quality of human life (Munro, 1995; Mitland \& Satterthwaite, 1996).

According to Newman (2002), the three key outcomes of sustainable housing consist of (1) ensuring a "roof overhead" for the housing disadvantaged; (2) ensuring housing be more eco-efficient, and sustainable in design and construction; and (3) ensuring housing is welllocated or helps create better locational amenity. Essentially, Newman refers to economical sustainability, environmental sustainability and social sustainability. This is supported by 
Bhatti (1997), who shows that environmental, economic and social processes of housing need have to be considered together, if moving towards sustainable housing, using a more rounded and comprehensive approach. To sum up, sustainable housing is the need to incorporate actively both environmental/ecological concerns with the issues of social justice, income generations and poverty eradication (Perkins and Thorns, 1999; Satterthwaite, 1999; PCE, 2002).

The issue of social sustainability is getting attention in the discussions of housing sustainability. Thorns (2004) interprets social sustainability as a relationship between house-home and links to the city and the neighbourhood. It is explained by Robbins (1998), that existing and new neighbourhoods can be "completed" in terms of mixed use and access to services and amenities. This viewpoint is further corroborated by Moorer and Suurmeijer (2001), that social networks, human relationships and psychological attachments can be developed and emerged over time.

What is mentioned above seems to be the primary aspect of a high-density urban structure. De Roo and Miller (2000) provide examples that several countries and regions around the world are promoting higher urban densities, in pursuit of a more sustainable housing development. In Hong Kong, high-density living makes the operation of public transport financially viable, enabling Hong Kong to develop one of the best public transport systems in the world (Chiu, 2000). Moreover, a compact/denser urban environment is considered more efficient and sustainable in terms of land resource management, as transportation, commercial and institutional facilities are more economically viable (Niam and Keung, 2004).

However, there are practically no measurable standards for many of the aspects discussed above, let alone conducting a quantitative assessment of the sustainability of the housing system or providing a framework for developing a sustainable housing strategy. There exist no studies specifically in the area of measuring housing sustainability in terms of housing market mechanisms. In the case of Hong Kong, the principal question is: which factors contribute to a sustainable housing system? This question is important if sustainable housing is to be achieved. This study attempts to inject a more market-oriented perspective into the formation of a sustainable housing policy through the housing space demand/supply dynamics. It is difficult, if not impossible, to decide "where to supply" and "how much to supply" without knowing the demand side of matters. No matter how environmentally sustainable an area is designated to be, it is not practical if no one wants to live in there. Therefore, by finding out the consumers' behaviours concerning housing, it is possible for government departments to adopt housing policies accordingly. 


\section{METHODOLOGY}

This research has adopted Chiu's (2003) framework in which the sustainability of housing policy is broken down into 4 aspects: environmental, social, cultural and economic sustainability. However, only 3 of the 4 aspects in Chiu's framework will be selected, due to difficulties in defining cultural sustainability in an area as tiny as Hong Kong. The conceptual framework of this research is illustrated in Figure 1.

Figure 1: The four components of the sustainability of housing (adopted from Chiu, 2003)

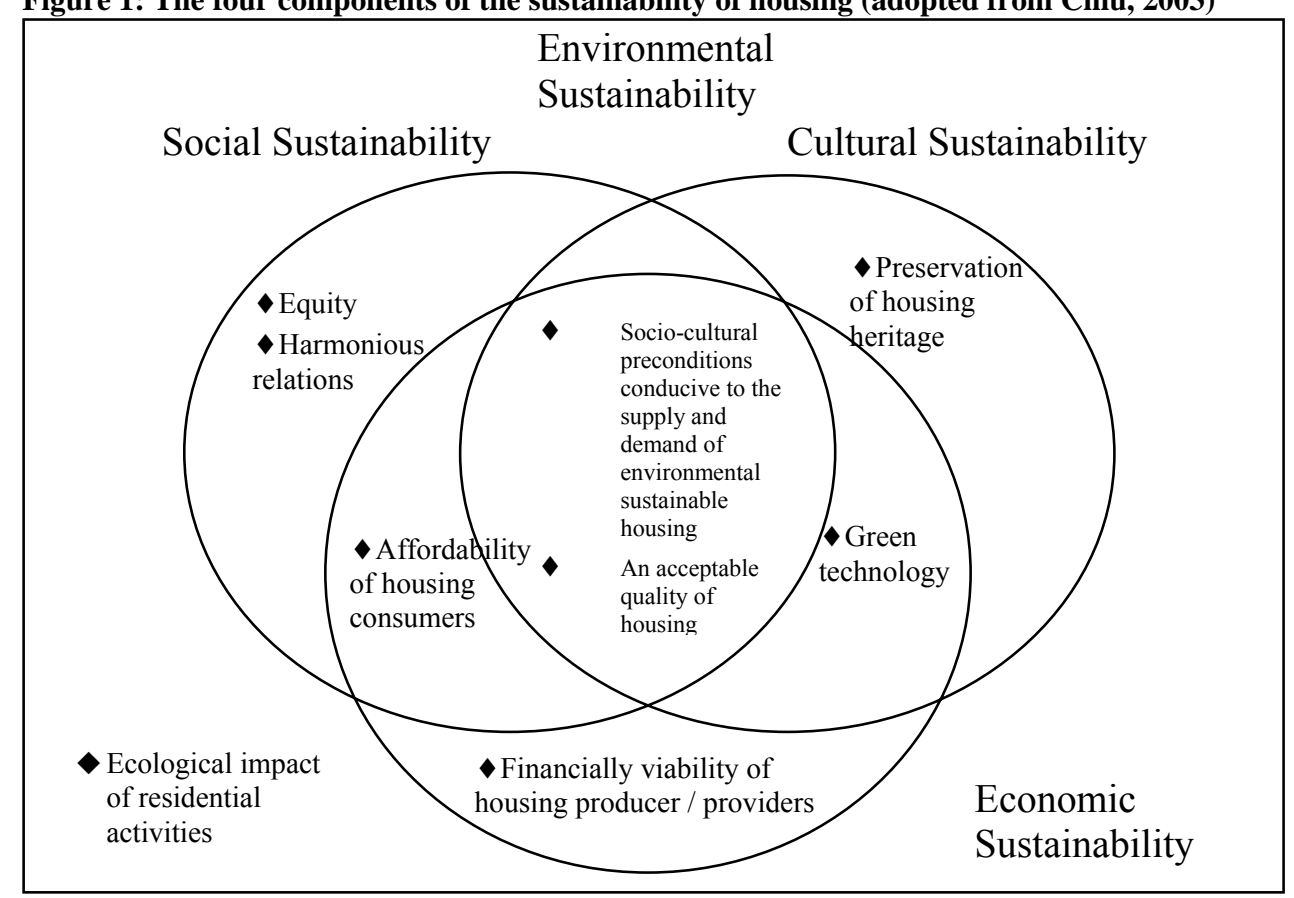

The study methodology involves a two-tier analytical framework. In the first stage, econometric modelling will be used to select the elements that are significantly correlated to housing floor area shortage or surplus, a proxy variable of housing market situations. As discussed in the literature review, there is a lack of consensus on what constitutes housing sustainability. In this research, housing space shortage or surplus is used to represent housing sustainability from consumers' point of view. This variable is used because housing shortages or surpluses are the result of discrepancies between demand and supply. Such demand and supply forces have different implications for housing sustainability. In the second stage, a cluster analysis will be employed to classify the selected districts into a number of clusters. The classification will be based on the similarities between the districts in terms their land use distributions. The characteristics of various clusters will provide 
some insights on the kind of housing different individuals would prefer, within a set of sustainability factors.

The two-tier analytical framework provides both a micro and macro investigation on the nature of housing sustainability. On the micro level, the econometric model enables us to identify the individual variables that are significantly correlated to housing floor space demand and supply conditions. On the macro level, the cluster analysis offers a way to classify different districts, based on sustainability elements. The two-tier analytical framework can provide a comprehensive, market-oriented understanding into the littleresearched area of housing sustainability.

\section{ECONOMETRIC MODELLING}

Most of the previous studies have examined housing prices, planning and economic factors in the context of land use policy and patterns. The work most relevant to this study is that by Son and Kim (1998). They stress that urban housing shortage/surplus is determined by the interaction of both demand and supply.

The framework of this paper is grounded on an analysis of the demand and supply of residential floor area. It is assumed that the housing demand and supply situations in the territory can be described by the following equations respectively.

$$
\begin{aligned}
& \mathrm{F}_{\mathrm{d}}=f(\text { POPDEN, PCSALE, RIR, INSTIT, TRANS) } \\
& \mathrm{F}_{\mathrm{s}}=f(\text { Land Supply, Plot Ratio) }
\end{aligned}
$$

$F_{d}$ is the floor area demanded by households and $F_{s}$ is available floor area in the market. The factors selected as determinants of $F_{d}$ include population density (POPDEN), per capita saleable floor area (PCSALE) and rental-income ratio (RIR), an institutional dummy variable (INSTIT) and an transport network dummy variable (TRANS). On the other hand, $\mathrm{F}_{\mathrm{s}}$ is largely determined by residential land supplied by the government and plot ratio. In other words, the planning system plays a key role in supplying land for residential use. The demand and supply factors will be discussed in the next section.

In a perfect market, the quantity demanded and quantity supplied of land will be at equilibrium (i.e. $F_{d}=F_{s}$ ). However, in reality, government policy, along with other factors, may distort the market mechanisms. As a result, the allocation of land use may deviate from the optimal level. In this paper, urban land shortage or surplus in a district $(S)$ is defined as the difference between the theoretical equilibrium floor space demanded $\left(F_{d}\right)$ and the floor space available $\left(F_{s}\right)$, in which positive value of $\mathrm{S}$ indicates a surplus on floor space while a negative value represents a shortage (see Equation 3).

$$
S=F_{S}-F_{d}
$$


Most of the previous studies have examined housing prices, planning and economic factors in the context of land use policy and patterns. Son and Kim (1998) suggest that the urban land shortage/surplus is determined by the interaction of demand and supply. With reference to previous studies and the availability of data in Hong Kong, relevant demand and supply factors have been selected and incorporated into our model. The model is used to predict a theoretical optimal level of floor space demanded by the district's households. It is constructed by employing demand and supply factors, which are considered to be influential in determining the amount of actual residential floor space used. The equation for the actual floor space in urban area is written as follows:

$\mathbf{F}_{\boldsymbol{d}}=\alpha_{1} \mathbf{R I R}+\alpha_{2}$ POPDEN $+\alpha_{3}$ PCSALE $+\alpha_{4}$ INSTIT $+\alpha_{5}$ TRANS $+\gamma$

where $\quad \mathbf{F}_{\boldsymbol{d}}=$ Theoretical floor space demanded in the district

$\mathbf{R I R}=$ Rental-Income ratio

POPDEN = Population density in the district

PCSALE $=$ Per capita saleable area in the district

INSTIT $=$ Institutional dummy variable $(1=$ The New Territories, $0=$ otherwise $)$

TRANS $=$ Transport network (or accessibility) dummy variable $(1=$ Districts that can be reached by MTR, $0=$ Otherwise)

$\gamma=$ constant

At equilibrium, the demand for floor space in a district equals the saleable floor area in the same district, which is $\mathbf{F}_{\boldsymbol{d}}=\mathbf{F}_{\boldsymbol{s}}$. Consequently, the equation becomes:

$\mathbf{F}_{s}=\alpha_{1}$ RIR $+\alpha_{2}$ POPDEN $+\alpha_{3}$ PCSALE $+\alpha_{4}$ INSTIT $+\alpha_{5}$ TRANS $+\gamma$

It is expected that each district will have a different urban land shortage/surplus situation as a unique land supply situation would occur under different geographical and planning constraints. Discussion of the factors in the equation and their respective hypotheses will be delineated in the next section. 


\section{DATA SOURCES}

This section discusses the sources of data and explains each variable and its hypothesized impact in detail. Relevant household data were extracted from the Annual Digest of Statistics and the Basic Tables for Tertiary Planning Units, issued by the Census and Statistics (C\&S) Department. The planning data were mainly collected from the Outline Zoning Plans issued by the Planning Department. The private and public residential floor area data were mainly provided by the Rating and Valuation Department. 38 districts are retained for analysis, as divided in accordance with the Planning Department.

\section{Variables influencing floor space demanded $\left(F_{d}\right)$}

(RIR) Rental-Income Ratio

This is the amount paid, by a domestic household, for renting an accommodation, divided by its household income as in March 2001. With the use of such ratio, we are able to know the portion of rental payment on household income, suggesting the affordability of households in a particular district. This ratio would rise, either by an increase in rent or a decline in household income in general. As a higher rental-income ratio implies more financial burden on a household, demand for space is likely to attenuate.

\section{(POPDEN) Population Density of the District}

It is usually assumed that a larger population will be correlated to a higher actual floor space used. But, if land provided for development is very limited, a higher level of population would induce a much higher population density. In other words, just viewing a situation without referring to the land area is not able for us to see the whole picture. A rise in population in a district would induce more demand for living space, but a rise in population density may lead to opposite results. Gathering the two elements, it is expected that population density would have a positive, albeit much neutralized, impact on demand for floor space.

\section{(PCSALE) Per Capita Saleable Area}

It should be noted that the saleable area in this case is viewed in a different light. Unlike the saleable area used as the actual floor space in the model, this is more of an indicator for people to make housing decisions. Per capita saleable area can be viewed, along with rent/price for living space, as the measuring stick for housing space demand decisions within a certain set of consumer's preferences. It is expected that a higher per capita saleable area in an area, which means either an increase in saleable area or a lower population, would incite a positive reaction concerning floor space demand.

\section{(INSTIT) Institutional Dummy Variable}

This dummy variable is specifically designed, based on the controversy from the land lease arrangements regarding land in the New Territories. Due to the unforeseen nature of land lease arrangements for New Territories before 1984, developers appeared to be reluctant to invest on projects in New Territories, despite a much larger amount of land available. It is 
assumed that the actual floor space available in New Territories would be lower than in other areas, under the same setting.

(TRANS) Transport Network (Proximity) Dummy Variable

The presence of MTR in a certain area not only improves the accessibility of the place, it also ascends the demand for living space there, thus the property prices. Therefore, a transport network dummy variable is formed, in order to explore the impact of the MTR factor to the floor space demanded in a district.

The Land Supply

Restrictive regulations on land development and land use limit the supply of urban land. It worsens the affordability problems of poorer renters and makes the transition from renting to owning less likely (Son and Kim 1998). Zoning is often used to prohibit higher densities, while policies such as building codes raise the cost of developing (Somerville 1995). In Hong Kong, there is a lack of readily available and easily interpretable measures of planning constraints. Therefore, perhaps the only feasible way to interpret planning constraints is through figures on the total saleable floor area in the districts.

\section{(Fs) Floor Space available in the district}

This variable adopts floor area as a proxy for land area due to data limitations. The land supply constraint influences housing production. In Hong Kong, the maximum allowable floor area developed is based on lease conditions, planning regulations and building regulations. Saleable floor area can be used as a proxy of floor space supply under planning constraints; for instance land supply, zoning and plot ratios. The reason behind the use of total saleable area in the districts is due to the difficulty to quantify various planning measures, hence the impact of planning on house space demand.

\section{Cluster analysis}

Cluster analysis is used to classify the selected districts into different groups in terms of sustainability. Cluster analysis is a group of multivariate techniques whose primary purpose is to group objects based on the characteristics they possess (Everitt, Landau \& Leese, 2001). Agglomerative Hierarchical Clustering is adopted in this paper. It is a statistical method for finding relatively homogeneous clusters of cases based on a basket of characteristics. It starts with each case in a separate cluster and then combines the clusters sequentially, reducing the number of clusters at each step until only one cluster is left. The clusters will be defined in terms of the correlations of sustainability factors between the districts.

The cluster analysis is able to produce numerous distant groups grounded on the districts' characteristics/attributes. Hitherto, the groups can be compared with one another, in terms of both the economic/environmental/social attributes and the demand/supply situations of 
the floor areas. While the former can be regulated institutionally, the latter is subject to market mechanisms. Therefore, comparing the various groups generated by the cluster analysis, we can find out whether sustainability and people's preferences on housing can co-exist, instead of conflict against each other.

\section{CROSS-SECTIONAL REGRESSION RESULTS}

The summary of the regression results is shown in Table 1.

Table 1: Summary of the regression results

\begin{tabular}{|c|c|c|c|c|c|c|}
\hline \multirow[t]{2}{*}{ Model } & & \multicolumn{2}{|c|}{ Unstandardized Coefficients } & \multirow{2}{*}{$\begin{array}{c}\begin{array}{c}\text { Standardized } \\
\text { Coefficients }\end{array} \\
\text { Beta }\end{array}$} & \multirow[t]{2}{*}{$\mathrm{t}$} & \multirow[t]{2}{*}{ Sig. } \\
\hline & & B & Std. Error & & & \\
\hline & Constant & 968959.313 & 603056.533 & & 1.607 & .118 \\
\hline & $\begin{array}{l}\text { Rental-Income } \\
\text { Ratio }\end{array}$ & -6896390.603 & 2030337.029 & -.327 & -3.397 & .002 \\
\hline & Population Density & 1990.541 & 242.035 & 1.021 & 8.224 & .000 \\
\hline & $\begin{array}{l}\text { Transport Network } \\
\text { Dummy }\end{array}$ & 466567.828 & 325381.770 & .118 & 1.434 & .161 \\
\hline & $\begin{array}{l}\text { Per Capita Saleable } \\
\text { Area }\end{array}$ & 43527.370 & 10789.813 & .350 & 4.034 & .000 \\
\hline & $\begin{array}{l}\text { Institutional } \\
\text { Dummy }\end{array}$ & -2901910.093 & 672150.757 & -.504 & -4.317 & .000 \\
\hline
\end{tabular}

Adjusted R-Square $=0.756$

All of the variables, with the exception of TRANS, are found to be significant at the 5\% level and the explanatory power of the equation is considered satisfactory (R-square $=$ 0.756). Two of the variables, PCSALE and TRANS, have a positive effect on the dependant variable, $\mathbf{F}_{\mathbf{d}}$. While POPDEN is found to have a positive impact on floor space demand in Hong Kong, different results may be yielded in cases outside Hong Kong. The other two variables, RIR and INSTIT, have negative repercussions on $\mathbf{F}_{\mathbf{d}}$. Generally, the results are consistent with our hypothesis.

An examination of the per capita floor area in each district is illustrated in Table 2. Floor area shortage/surplus (in percentage) is also listed for each district. This figure is deciphered as a proxy for urban land surplus or shortage. 
Table 2: Housing floor area shortage/surplus situation of the Districts

\begin{tabular}{|c|c|c|}
\hline Districts & $\begin{array}{l}\text { Floor Area Shortage } \\
(-) / \text { Surplus (+) (\%) }\end{array}$ & $\begin{array}{l}\text { Saleable Floor area per } \\
\text { person }\left(\mathrm{m}^{2}\right)\end{array}$ \\
\hline \multicolumn{3}{|l|}{ Cluster 1} \\
\hline $\begin{array}{l}\text { 1. Kennedy Town and } \\
\text { Mount Davis }\end{array}$ & -15.47 & 14.68 \\
\hline $\begin{array}{l}\text { 2. Sai Ying Pun and } \\
\text { Sheung Wan }\end{array}$ & -36.45 & 14.22 \\
\hline 3. Wanchai & -23.14 & 17.01 \\
\hline 4. Causeway Bay & -57.05 & 39.81 \\
\hline 5. Wong Nai Chung & 67.48 & 28.89 \\
\hline 6. $\quad$ North Point & 36.96 & 17.79 \\
\hline 7. Mid-level East & -7.22 & 34.20 \\
\hline 8. $\quad$ Mid-level West & 69.98 & 34.34 \\
\hline $\begin{array}{l}\text { 9. Aberdeen \& Ap Lei } \\
\text { Chau }\end{array}$ & 41.54 & 14.36 \\
\hline 10. Quarry Bay & 43.54 & 20.62 \\
\hline 11. Shau Kei Wan & 4.81 & 31.03 \\
\hline 12. Tsim Sha Tsui & -8.88 & 32.49 \\
\hline 13. Yau Ma Tei & -48.49 & 20.56 \\
\hline 14. Mongkok & -28.03 & 16.14 \\
\hline 15. Cheung Sha Wan & -3.77 & 14.07 \\
\hline 16. Lai Chi Kok & -13.74 & 17.95 \\
\hline 17. Hung Hom & -20.87 & 17.85 \\
\hline 18. Ma Tau Kok & -76.12 & 12.19 \\
\hline 19. Kowloon Tong & 11.87 & 26.67 \\
\hline $\begin{array}{l}\text { 20. Tse Wan Shan, } \\
\text { Diamond Hill \& San } \\
\text { Po Kong }\end{array}$ & 11.95 & 24.18 \\
\hline 21. Ngau Chi Wan & -95.97 & 11.07 \\
\hline $\begin{array}{l}\text { 22. Ngau Tau Kok and } \\
\text { Kowloon Bay }\end{array}$ & -75.99 & 8.33 \\
\hline $\begin{array}{l}\text { 23. Cha Kwo Ling, Yau } \\
\text { Tong \& Lei Yue Mun }\end{array}$ & 17.69 & 14.78 \\
\hline 24. Kwun Tong (South) & 15.75 & 24.45 \\
\hline 25. South West Kowloon & 2.97 & 57.22 \\
\hline $\begin{array}{l}\text { 26. Wang Tau Hom \& } \\
\text { Tung Tau }\end{array}$ & 26.56 & 28.76 \\
\hline 27. Tseung Kwan $\mathrm{O}$ & -4.61 & 15.26 \\
\hline 28. Ma On Shan & 34.70 & 15.28 \\
\hline 29. Tuen Mun & -7.89 & 18.72 \\
\hline 30. Tai Po & -4.92 & 14.45 \\
\hline
\end{tabular}




\begin{tabular}{|c|c|c|}
\hline 31. Yuen Long & 46.79 & 27.61 \\
\hline 32. Tsuen Wan & 58.82 & 49.45 \\
\hline Cluster 2 & 87.27 \\
\hline $\begin{array}{l}\text { 33. Shouson Hill and } \\
\text { Repulse Bay }\end{array}$ & -283.26 & 54.82 \\
\hline 34. The Peak Area & -137.09 & 15.67 \\
\hline 35. Central District & -241.90 & 15.99 \\
\hline 36. Stanley Chung Town & -207.85 & 44.06 \\
\hline $\begin{array}{l}\text { 37. Centre Area } \\
\text { Cluster 3 Jardine's Lookout \& }\end{array}$ & -1337.04 & \\
\hline 38. Wong Nai Chung Gap & 65.96 & 22.30 \\
\hline Overall & 4.00 & 25.65 \\
\hline
\end{tabular}

\section{CLUSTER ANALYSIS}

A cluster analysis has been performed, in order to gather districts which share similar characteristics, based on the correlations on the figures of the aforementioned nine variables between the 38 districts in this study. The results are shown as follows:

Figure 2: Results of the cluster analysis

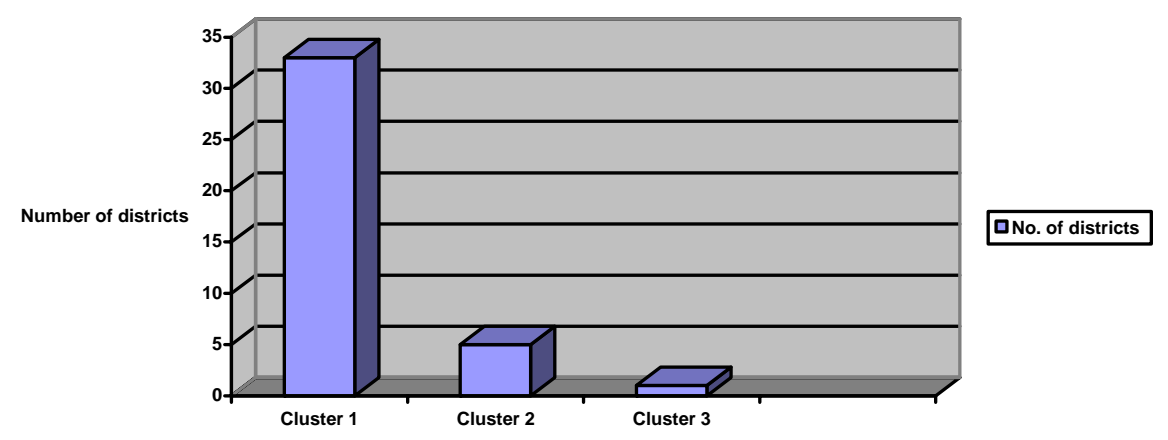


Table 3: Cluster characteristics (the mean)

\begin{tabular}{|l|c|c|c|c|c|}
\hline & $\begin{array}{c}\text { Housing Floor } \\
\text { Space } \\
\text { shortage/ } \\
\text { Surplus (\%) }\end{array}$ & $\begin{array}{c}\text { \% of } \\
\text { residential } \\
\text { zoning }\end{array}$ & $\begin{array}{c}\text { \% of commercial } \\
\text { and industrial } \\
\text { zoning }\end{array}$ & $\begin{array}{c}\text { \% of } \\
\text { greenbelt, } \\
\text { open space } \\
\text { and country } \\
\text { park zoning }\end{array}$ & $\begin{array}{c}\text { \% of } \\
\text { government, } \\
\text { institution/ } \\
\text { community } \\
\text { zoning }\end{array}$ \\
\hline Cluster 1 & 1.13 & 25.76 & 5.81 & 32.93 & 13.04 \\
\hline Cluster 2 & -441.43 & 16.19 & 6.11 & 52.12 & 10.27 \\
\hline Cluster 3 & 65.96 & 17.35 & 0.24 & 77.04 & 2.46 \\
\hline \% of road & $\begin{array}{c}\text { Population } \\
\text { zoning }\end{array}$ & $\begin{array}{c}\text { Pen Capita } \\
\text { henstare) }\end{array}$ & $\begin{array}{c}\text { Average } \\
\text { Household } \\
\text { (meter square) }\end{array}$ & $\begin{array}{c}\text { Rent-to- } \\
\text { income }\end{array}$ & \\
\hline Cluster 1 & 19.43 & 922.36 & 22.26 & 26076.2 & 0.19 \\
\hline Cluster 2 & 15.32 & 34.26 & 43.56 & 40211.4 & 0.24 \\
\hline Cluster 3 & 2.91 & 81.74 & 22.30 & 53471 & 0.29 \\
\hline
\end{tabular}

On average, imbalance in floor space demand/supply situations is at a minimal level. However, there are vastly different outcomes when looking at the three clusters individually. The three clusters represent different levels of sustainability. An optimally sustainable district is the one with environmental quality without sacrificing economic vitality. Since environmental concerns have become a major topic in sustainability, we start with cluster 3, which the highest portion of land is allocated for greenbelts and open spaces. The relatively lack of roads seem to suggest a more environmental-friendly living environment. But it is also obvious that most people cannot even afford the living cost in areas with structures similar to a cluster 3 district. In hindsight, the district in cluster 3 is economically unsustainable, as it is defies the principle of affordable housing.

Districts in cluster 1 have a compact setting, with the presence of the major functions of society. It has the highest portion of land used for GIC, residential, roads, commercial. On the one hand, the compact setting in cluster 1 areas can be sustainable in a land resource management sense. It is also economically sustainable. On the other hand, it is far from environmental sustainability. Though the compact setting in cluster 2 districts induce efficient land use, it also lead to a higher population density. Because of such, the per capita saleable floor area available is at a low level. The seemingly balanced demand/supply situation in cluster 1 districts in general suggests a couple of things. First, the cost of living in cluster 1 areas is considered the lowest, including the cost of travelling. Then, the community-oriented setting makes the areas socially sustainable. Nevertheless, the externalities associated with the compact setting push people away. The little floor area surplus in cluster 1 districts is the result of the above factors cancelling one another out. 
In cluster 2 districts, allocation of land for various uses appear to be in between those of cluster 1 and 3. Discounting the figures of Central (a unique case, which its land use is predominantly commercial in nature), cluster 2 districts have a residential area higher than cluster 3 , but lower than cluster 1 . Cluster 2 districts are more economically sustainable than the cluster 3 district and more environmentally sustainable than cluster 1 districts. The per capita floor area available is almost twice as high as that of both cluster $1 \& 3$ districts. This, along with the lowest population density, is a major pull factor for people who prefer a more spacious living environment, without sacrificing much on other aspects of society. The attractiveness of cluster 2 areas is evident judging from the massive amount of floor area shortages in the cluster 2 districts.

\section{IMPLICATIONS}

The results suggest that the government should strive to achieve a balanced, yet flexible, housing policy. From an institutional perspective, the key issue appears to be the provision of adequate and affordable housing to the disadvantaged strata of the population in Hong Kong, especially in densely-populated areas. Public rental housing will still be justified of its existence, despite the recent turn of events in which the government is anticipated to play a much less active role in the housing market. Nevertheless, public rental housing should remain an important component in the housing market to ensure the sustainable housing development in Hong Kong. With the limitations on land resources in Hong Kong, urban renewal can be another method. With more flexible policies on issues such as plot ratios, it is an alternative to improve the living environment of the older districts, without taking away the existing social sustainability in the process.

Also, a flexible housing policy is needed because housing policies, based on one set of arrangements (i.e. zoning), are not able to please the whole population. It is due to the vast differences in individuals' preferences regarding the kind of home they want to have. For instance, a particular population group may prefer crowded places with a sense of community and opportunities for interactions, while another group of people may prefer something else, like a quiet, more spacious living environment. So the government cannot force the latter population group to accept what the government thinks is good for them. As we can see, there are very high levels of housing floor space shortages in cluster 2 districts. Meanwhile, shortages can also be found even in the most densely-populated areas (in cluster 1). Private participations can be the cure of this issue, but only with flexible enough land use policies to attract them. Meeting the needs of the current generation without hurting future generations is one thing; the impractical nature of providing the same set of constraints to all of the population is another. Considering the void of land resources and the rather stable population growth in Hong Kong, a sustainable housing policy should primarily take care of current people's needs and government planning should mainly focus on those who need basic accommodation the most. 


\section{CONCLUSION}

This research has explored the issue of housing sustainability in Hong Kong. Due to the difficulties in quantifying elements like environmental sustainability among others, this study looks at the issue of housing sustainability in a more economic-oriented approach. In this research, three aspects of sustainability: economic, environmental, and social sustainability have been adopted in the analytical framework. Sustainability of selected districts is assessed by these criteria. A two-tier analytical framework has been employed, representing both a micro (regression on residential floor space shortages/surpluses) and a macro (cluster analysis) point of view, respectively. The findings suggest that the government should adopt a housing policy that emphasizes a balanced development between the public and private sectors, as sustainable housing policies cannot be made with only one set of highly controversial optimal mix of criteria. Individuals' preferences on housing have to be considered as well. The study suggests that the government should focus on the improvement of older, lower-income districts; for instance, through urban renewal, without usurping the existing social sustainability these districts possess. As far as any possible conflicting generational interests are concerned, providing the constraints on land resources in Hong Kong, in addition to the much declining population growth in recent years, more weight should be put on the needs of the present generation regarding housing policies.

\section{REFERENCES}

Beatley, T. \& Manning, K. (1997), The ecology of space: planning for environment, economy and community. Washington, DC: Island Press.

Chiu, R. L. H. (2000). Environmental Sustainability of Hong Kong's Housing System and the Housing Process Model, International Planning Studies, 5(1), 45 - 64.

Chiu, R. L. H. (2003). Sustainable development: a new perspective for housing development. Paper presented at the National Housing Conference, Adelaide, Australia.

De Roo, G. \& Miller, D. (Eds.) (2000), Compact cities and sustainable development: a critical assessment of policies and plans from an international perspective. Aldershot, UK: Ashgate.

Everitt, B. S., Landau, S., \& Leese, M. (2001), Cluster Analysis. London: Arnold.

Hong Kong Housing Bureau (1998), Homes for Hong Kong people: the way forward-long term housing strategy review consultative document. Hong Kong: Housing Bureau, Government Secretariat.

Hong Kong SAR Government (1999), Sustainable development in Hong Kong for the $21^{\text {st }}$ century. Hong Kong SAR: Government Printer. 
Huang, S. L., Wong, J. H., \& Chen, T. C. (1998), A framework of indicator system for measuring Taipei's urban sustainability. Landscape and Urban Planning, 42, 15-27.

Jarvis, H. (2003), Dispelling the myth that preference makes practice in residential location and transport behaviour, Housing Studies, 18(4), 587-606.

Leung, C. Y. (2000, June), Building sustainability in a globalized world: Hong Kong's sustainable future. Paper presented at the Decision makers 2010: building sustainability in a globalized world conference, Hong Kong, China.

Moorer, P. and Suurmeijer, T.P.B.M. (2001), The Effects of Neighbourhoods on Size of Social Network and the Elderly and Loneliness: A Multi-Level Approach. Urban Studies, 38, 105-118.

Newman, P. (2002), Sustainability and Housing: More than a roof over head, Conference Paper for 2002 Barnett Oration, Melbourne, October 31.

Niam, C.M. and Keung, K.Y. (2004), Improving the Hardware, Retaining the Heartware The Singapore Way to Sustainable Housing, Conference Paper for the International Housing Conference in Hong Kong 2004.

Perkins, H and Thorns, D. C and Field, M (1999), Urban Sustainability: an annotated Bibliography, House and Home Project, Canterbury and Lincoln Universities,

Planning Department (1999), The Survey of Housing Aspirations of Households (Executive Summary), Hong Kong Government Printer.

Robbins E, (1998), The New Urbanism and the Fallacy of Singularity, Urban Design, 3(1), 33-42.

Rowan-Robinson, J., Ross, A. \& Walton, W. (1995), Sustainable development and the development control process. Town Planning Review, 66(3), 269-286. 
Satterthwaite, D. 1999, The Earthscan Reader in Sustainable Cities, Earthscan Publications, London.

Son, J.Y. and Kim, K.H. (1998), Analysis of urban land shortages: the case of Korean cities, Journal of Urban Economics, 43, 362-384.

Thorns, D.C. (2004), Creating Sustainable Housing: The challenge of moving beyond environmentalism to new models of social development, Conference Paper for the International Housing Conference in Hong Kong 2004.

Wilson, A.G. (1974), Urban and Regional Models in Geography and Planning, London: John Wiley \& Sons. 